\title{
Effects of a Groundwater Heat Pump on Thermophilic Bacteria Activity
}

\author{
Heejung Kim ${ }^{1}(\mathbb{D})$ and Jin-Yong Lee ${ }^{2,3, * \mathbb{C}}$ \\ 1 The Research Institute for Earth Resources, Kangwon National University, Chuncheon 24341, Korea; \\ re503@snu.ac.kr \\ 2 Department of Geology, Kangwon National University, Chuncheon 24341, Korea \\ 3 Critical Zone Frontier Research Laboratory (CFRL), Kangwon National University, Chuncheon 24341, Korea \\ * Correspondence: hydrolee@kangwon.ac.kr; Tel.: +82-33-250-7723
}

Received: 2 September 2019; Accepted: 4 October 2019; Published: 6 October 2019

\begin{abstract}
Groundwater samples were collected from the tubular wells of a groundwater heat pump (GWHP), and the psychrophilic, mesophilic, and thermophilic bacteria inhabiting the collected groundwater were cultured and isolated. Using the isolated bacteria, we analyzed temperature-dependent changes in autochthonous bacteria based on the operation of the GWHP. Microbial culture identified eight species of bacteria: five species of thermophilic bacteria (Anoxybacillus tepidamans, Bacillus oceanisediminis, Deinococcus geothermalis, Effusibacillus pohliae, and Vulcaniibacterium thermophilum), one species of mesophilic bacteria (Lysobacter mobilis), and two species of psychrophilic bacteria (Paenibacillus elgii and Paenibacillus lautus). The results indicated A. tepidamans as the most dominant thermophilic bacterium in the study area. Notably, the Anoxybacillus genus was previous reported as a microorganism capable of creating deposits that clog above-ground wells and filters at geothermal power plants. Additionally, we found that on-site operation of the GWHP had a greater influence on the activity of thermophilic bacteria than on psychrophilic bacteria among autochthonous bacteria. These findings suggested that study of cultures of thermophilic bacteria might contribute to understanding the bio-clogging phenomena mediated by A. tepidamans in regard to GWHP-related thermal efficiency.
\end{abstract}

Keywords: groundwater heat pump; culturable bacteria; thermophilic bacteria; Anoxybacillus

\section{Introduction}

Renewable energy is collected from renewable sources, such as sunlight, wind, rain, tides, waves, and geothermal heat [1,2], whereas geothermal energy describes heat derived from the Earth, and represents both clean and sustainable energy. The increase in fuel and environmental costs related to the use of fossil fuels has made renewable and efficient energy systems more accepted. This has been reflected in the increased use of groundwater heat pumps (GWHP) for heating and cooling systems in commercial and residential buildings [3]. Numerous ongoing studies are focused on the technical aspects of this field $[4,5]$, as well as the groundwater and soil pollution caused by the installation and operation of a GWHP $[3,6]$.

Use of geothermal heat pump cooling and heating systems has experienced rapid growth in Germany, Denmark, Switzerland, Norway, France, Canada, the United States, the Netherlands, and China [7-15]. Geothermal energy has long been acknowledged as a highly efficient method for cooling and heating buildings, and a variety of geothermal heat pumps have, thus, been installed in general residential and commercial structures [16-21]. In Korea, heat pump cooling and heating systems are being installed mainly in large buildings, such as new buildings built for public institutions, commercial use, welfare facilities, and schools $[3,6,7,22]$. 
The benefits of geothermal energy provided by these systems support market demands, including providing low operating costs, eco-friendliness, and compatibility with building designs. Additionally, geothermal systems, such as those based on the use of groundwater, reportedly ensure high efficiency as the most stable, eco-friendly, and low-cost options among currently available cooling and heating systems, and have promoted increased related academic research $[4,21]$.

GWHP systems need an aquifer with a high transmissivity and adequate recharge, as well as adequate water quality to avoid corrosion, scaling, and well clogging. The high groundwater yield (the volume of exploitable groundwater) should be combined with relatively high natural water levels and the presence of rocks to prevent inner-well destruction at the junction of circulation between groundwater and the injected circulating water. Additionally, the water quality should be adequate enough to prevent corrosion or scaling phenomena, and a hydrogeothermal system is required to prevent radical, long-term temperature fluctuations at the entry to the geothermal source, normally caused by a circulating water temperature. A sudden fall in pumping level during groundwater collection can result in excessive power costs, resulting in inefficient and higher-cost operation.

Notably, for the GWHP, problems of thermal efficiency due to inevitable physicochemical and microbiological factors have been identified in several studies [23-25]. The efficiency of the tubular wells continuously used for long periods decreases upon clogging through the mechanical process associated with erosion of the underwater pump, chemical processes associated with mineral precipitation due to water-rock reactions, and biological processes related to biomass accumulation due to bacterial activity. Such phenomena might also reduce thermal efficiency and the quantity of water collected by the GWHP, as well as water quality [26-32]. Among these problems, microorganisms can negatively influence the thermal efficiency of the geothermal system by mediating the bio-clogging phenomena [6,25]. However, there has been a general lack of studies on the effects of temperature changes due to the operation of a GWHP on the composition of autochthonous bacteria. Therefore, we performed analytical experiments on psychrophilic, mesophilic, and thermophilic bacteria in seasonal groundwater samples collected from a GWHP system and evaluated temperature-dependent changes in autochthonous bacteria based on GWHP operation.

\section{Study Area and Methods}

\subsection{Study Area}

The study area was located in Janghak-ri, Dong-myeon, Chuncheon-si, Gangwon-do, Korea, and had geological features that included Chuncheon granite rocks and Mesozoic granite as the bedrock, with a quaternary alluvium layer covering the upper level (Figure S1 in Supplementary Materials) [6]. The geothermal wells for the study area were $200 \mathrm{~mm}$ in diameter and $250 \mathrm{~m}$ deep. The drilling results identified distributions for the alluvium layer (0-9 m), weathered rocks (10-15 m), soft rocks (16-26 m), and moderate rocks $(>26 \mathrm{~m})$.

The hydraulic conductivity of the study area was $1.92 \times 10^{-4} \mathrm{~cm} /$ day, and the transmissivity was $0.10 \mathrm{~m}^{2} /$ day. A step-drawdown test to determine the optimal yield and well efficiency at the study site revealed a yield of $240 \mathrm{~m}^{3} /$ day and a well efficiency of $66.0 \%$. The permeability of the testbed was $6.0 \times 10^{-12} \mathrm{~m}^{2}$, and the coefficient of transmissivity was $17.50 \mathrm{~m}^{2} /$ day. Thermal properties, such as thermal conductivity, well-flow rate, and thermal power of the GWHP circulating water were $3.23 \mathrm{~W} / \mathrm{mK}, 432 \mathrm{~m}^{3} /$ day, and $98.2 \mathrm{~kW}$, respectively. The geothermal wells were installed in August 2014, and water sampling was conducted seven times for microbial analysis until November 2016 (13 August 2014; 28 October 2014; 2 December 2014; 9 November 2015; 27 May 2016; 25 August 2016; and 24 November 2016) (Figure 1). The natural groundwater at the study area exhibited a steady range that reflected the annual mean temperature of the atmosphere, whereas the water temperature displayed a gradually increasing trend due to the influence of the ground temperature toward the core. The mean temperature of the circulating water in the GWHP was $16.1^{\circ} \mathrm{C}$. The system operated 
from 22:00 to 07:30, for $9 \mathrm{~h}$ and $30 \mathrm{~min}$, with coefficients of performance of 3.1 and 3.2 for cooling and heating, respectively [6].

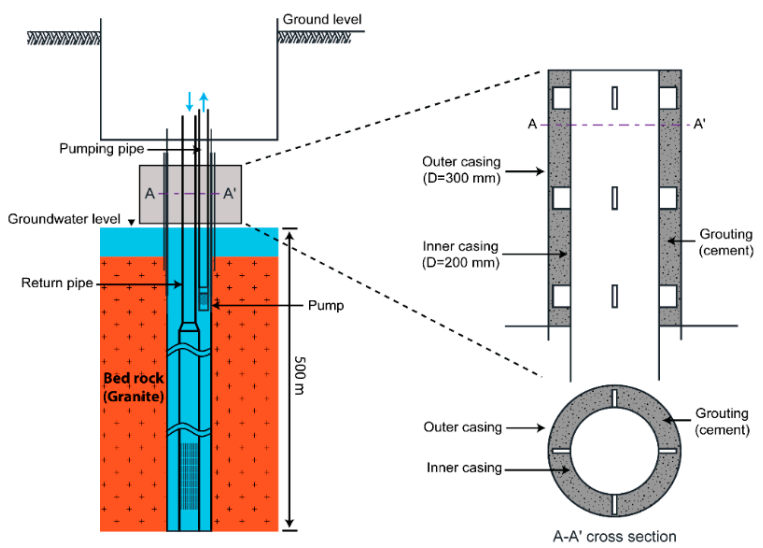

Figure 1. Schematic diagram of the groundwater heat pump (GWHP) well (adapted from Kim et al. [6]).

\subsection{Physicochemical Analysis}

Groundwater samples were collected seven times during the period between 13 August 2014, and 24 November 2016 (13 August 2014; 28 October 2014; 2 December 2014; 9 November 2015; 27 May 2016; 25 August 2016; and 24 November 2016). The collected groundwater was filtered using a $0.45-\mu \mathrm{m}$ membrane filter, and a quantity of the filtered sample was acidized using concentrated nitric acid ( $\mathrm{pH}$ 2.0). The water temperature, $\mathrm{pH}$, dissolved oxygen (DO), oxidation reduction potential (ORP), and electric conductivity (EC) were measured on site using a portable hydrometer (ProDSS; YSI, Yellow Springs, $\mathrm{OH}, \mathrm{USA})$. The concentrations of the main cations $\left(\mathrm{Ca}^{2+}, \mathrm{Mg}^{2+}, \mathrm{Na}^{+}\right.$, and $\left.\mathrm{K}^{+}\right)$and anions $\left(\mathrm{Cl}^{-}\right.$, $\mathrm{NO}_{3}{ }^{-}, \mathrm{SO}_{4}{ }^{2-}$, and $\mathrm{HCO}_{3}{ }^{-}$) were analyzed using inductively coupled plasma and ion chromatography mass spectrometry, respectively, by the Natural Science Research Center of the Industry-University Cooperation Group at Sangji University (Wonju, Korea).

\subsection{Microbial Isolation and Culture}

To analyze the culturable bacteria, the filtered contents in the stored filters were retrieved. A $0.20 \mu \mathrm{m}$ membrane filter was immersed in $100 \mathrm{ml}$ sterilized distilled water, and for DNA recovery, it was placed in a shaking incubator at $28^{\circ} \mathrm{C}$ for $48 \mathrm{~h}$. All pretreatment processes were performed using aseptic techniques. The medium used for sample treatment was R2A agar (Difco Laboratories Inc., Detroit, MI, USA). Following serial dilution of the pretreated sample as the stock, $100 \mu \mathrm{L}$ was inoculated and streaked onto the medium, followed by culture at $10^{\circ} \mathrm{C}, 28^{\circ} \mathrm{C}$, and $45^{\circ} \mathrm{C}$ for $48 \mathrm{~h}$. Colony counts were then performed and presented colony forming units $(\mathrm{CFU}) / \mathrm{L}$.

\subsection{Bacterial Identification}

To isolate and store thermophilic and psychrophilic/mesophilic bacteria, a visible colony of one species of dominant culturable bacteria and a colony of one random species were isolated. For thermophilic bacteria, two species were isolated per sample and stored in $20 \%$ glycerol at $-70{ }^{\circ} \mathrm{C}$. For psychrophilic/mesophilic bacteria, due to the small number of colonies, a total of three colonies were isolated from SY-3 samples and stored in $20 \%$ glycerol at $-70^{\circ} \mathrm{C}$.

To extract nucleic acids from the isolated bacteria, the InstaGene Matrix system (Bio-Rad, Hercules, CA, USA) was used. Briefly, $20 \mu \mathrm{L}$ of InstaGene Matrix was placed in a sterilized polymerase chain reaction (PCR) tube, and a sterilized toothpick was used to collect and transfer a single colony into the tube. Using a thermocycler, the reaction was performed at $99^{\circ} \mathrm{C}$ for $8 \mathrm{~min}$, followed by centrifugation at 13,000 rpm and removal of the supernatant. For DNA amplification, we used AccuPower HotStart PCR PreMix (Bioneer, Daejeon, Korea) in a $20 \mu \mathrm{L}$ reaction containing $1 \mu \mathrm{L}$ of 10 pmol of each primer 
used to amplify bacterial $16 \mathrm{~S}$ rRNA [8-27F (5'-AGA GTT TGA TCM TGG CTC AG-3') and 1,510-1,492R (5'-GGT TAC CTT GTT ACG ACT T-3')] and $1 \mu \mathrm{L}$ of the extracted nucleic acid template. The PCR conditions were as follows: initial denaturation at $95^{\circ} \mathrm{C}$ for $3 \mathrm{~min}, 30$ cycles of denaturation at $95^{\circ} \mathrm{C}$ for $1 \mathrm{~min}$, annealing at $55^{\circ} \mathrm{C}$ for $1 \mathrm{~min}$, and extension at $75^{\circ}$ for $1.5 \mathrm{~min}$, followed by a final extension at $72{ }^{\circ} \mathrm{C}$ for $8 \mathrm{~min}$.

To confirm the results of DNA amplification, products were electrophoresed at $135 \mathrm{~V}$ for $35 \mathrm{~min}$ in agarose gels in 1.2\% 1× TAE buffer stained with TopRed nucleic acid gel stain (Biopure, Horndean, UK), and the resulting bands were examined under ultraviolet light. Purification of the PCR products was performed using a QIAquick PCR purification kit (Qiagen, Hilden, Germany) according to manufacturer instructions, resulting in acquisition of a $20 \mu \mathrm{L}$ sample. Sequencing was performed by Macrogen (Seoul, Korea), and sequences were analyzed using PHYDIT software (v.3.2; http://plaza.snu.ac.kr/ \{\}jchun/phydit/). Identification was confirmed using query sequences entered into the EZBioCloud server (http://www.ezbiocloud.net).

\section{Results and Discussion}

\subsection{Physicochemical Composition}

The temperature of the groundwater collected from the tubular wells installed at the GWHP in the study area displayed a considerably wide range $\left(12.5-21.5^{\circ} \mathrm{C}\right)$ due to the influence of the GWHP system. We observed a particularly distinct seasonal fluctuation, with the highest and lowest levels reached during summer $\left(21.5^{\circ} \mathrm{C}\right)$ and winter $\left(12.5^{\circ}\right)$, respectively, and a comparatively high water temperature detected in October 2014 and August 2015. The EC ranged from $186 \mu \mathrm{S} / \mathrm{cm}$ to $350 \mu \mathrm{S} / \mathrm{cm}$, with the lowest and highest values obtained in May $2016(186 \mu \mathrm{S} / \mathrm{cm})$ and August $2016(350 \mu \mathrm{S} / \mathrm{cm})$, respectively. Exclusion of these two values resulted in a relatively stable range $(204-254 \mu \mathrm{S} / \mathrm{cm})$ (Figure 2). The $\mathrm{pH}$ ranged from 4.4 to 8.3, although exclusion of values obtained in July 2016 returned a range of 6.0 to 8.3 , with no seasonal fluctuation in $\mathrm{pH}$ observed. The DO ranged from $1.42 \mathrm{mg} / \mathrm{L}$ to $5.88 \mathrm{mg} / \mathrm{L}$, with relatively high values $(4.10 \mathrm{mg} / \mathrm{L})$ found exclusively in the summer during in-flow of river water, whereas other seasons showed similar values $(2.23 \mathrm{mg} / \mathrm{L})$.
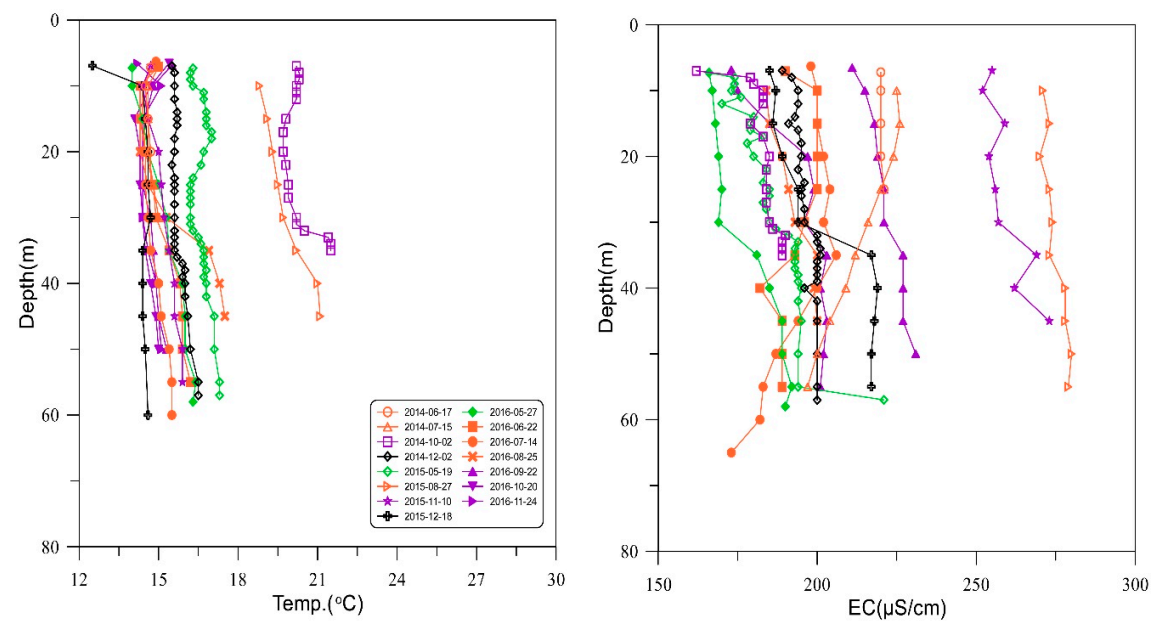

Figure 2. Temperature and EC values with depths.

We observed a marked increase in EC in August and November of 2015, which was attributed to the inefficient circulation of groundwater at the geothermal wells that caused different EC between the upper and lower levels of groundwater [6]. The main chemical composition of the collected samples is presented as a Piper diagram (Figure 3a). The overall geochemical characteristics of the groundwater in the study area identified it as $\mathrm{Ca}-\mathrm{HCO}_{3}$-type groundwater with relatively low depth. Although some samples indicated an increased contribution of $\mathrm{Na}^{+}$and $\mathrm{K}^{+}$, the majority of samples 
showed steady values for contributions by the main cations and anions. A similar pattern to that observed in the Piper diagram was observed in a Durov diagram (Figure 3b). In agreement with the Piper diagram, groundwater quality did not show significant compositional changes with respect to the anions; however, an increase in the cations $\mathrm{Na}^{+}$and $\mathrm{K}^{+}$was identified in the Durov diagram. The $\mathrm{Ca}-\mathrm{HCO}_{3}$ classification presented by the Piper and Durov diagrams generally indicates the type of natural groundwater quality relatively less affected by pollution [33-35]. Furthermore, the (total dissolved solid) value ranged from $106.4 \mathrm{mg} / \mathrm{L}$ to $134.1 \mathrm{mg} / \mathrm{L}$. Along with the increasing trend in TDS, we observed increasing trends for $\mathrm{Ca}^{2+}, \mathrm{Mg}^{2+}, \mathrm{NO}^{3-}, \mathrm{Cl}^{-}, \mathrm{SO}^{2-}$, and $\mathrm{HCO}^{3-}$ contents, with the most distinct trends exhibited by $\mathrm{Ca}^{2+}, \mathrm{SO}^{2-}$, and $\mathrm{HCO}^{3-}$, and no clear correlations identified for $\mathrm{Na}^{+}, \mathrm{K}^{+}$, and $\mathrm{NO}^{3-}$ (Figure 4). These findings indicated that changes in hydrogeochemical properties according to the GWHP operation were not distinct. Nevertheless, geophysicochemical analysis should continue to be conducted, as such analyses often provide basic data for use in developing response measures necessary for the preservation and management of surrounding groundwater quality required for system operation.
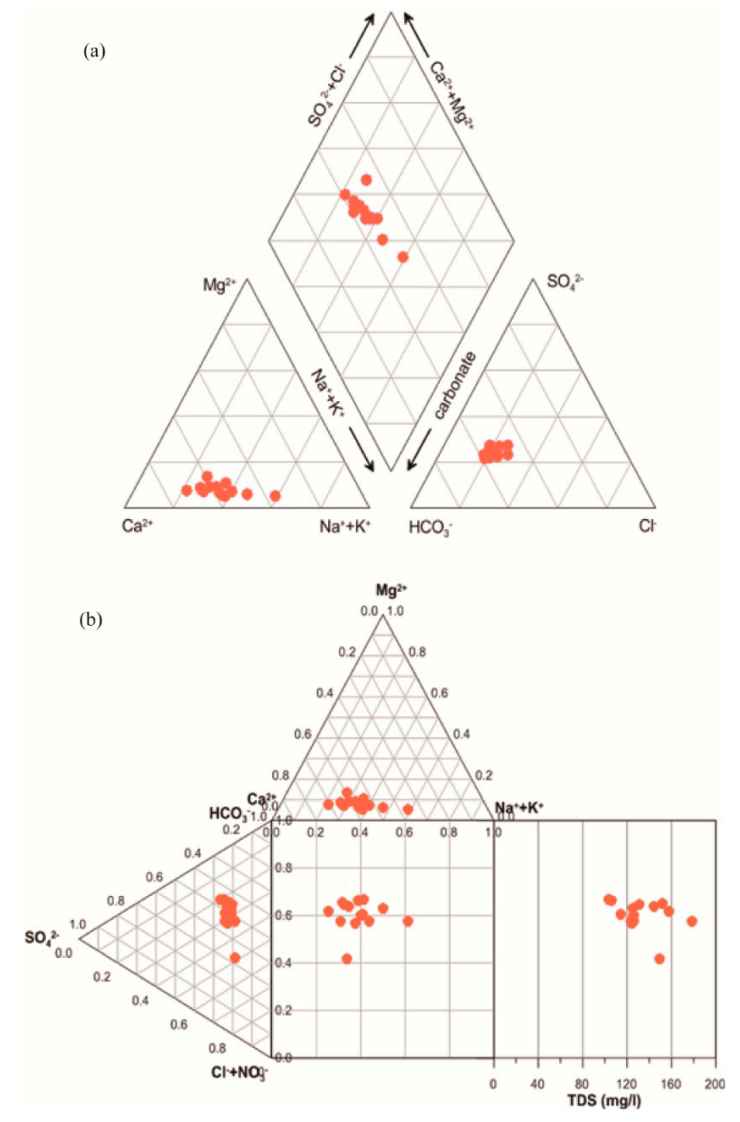

Figure 3. (a) Piper and (b) Durov diagrams showing the hydrogeochemical evolution of SY-3. 

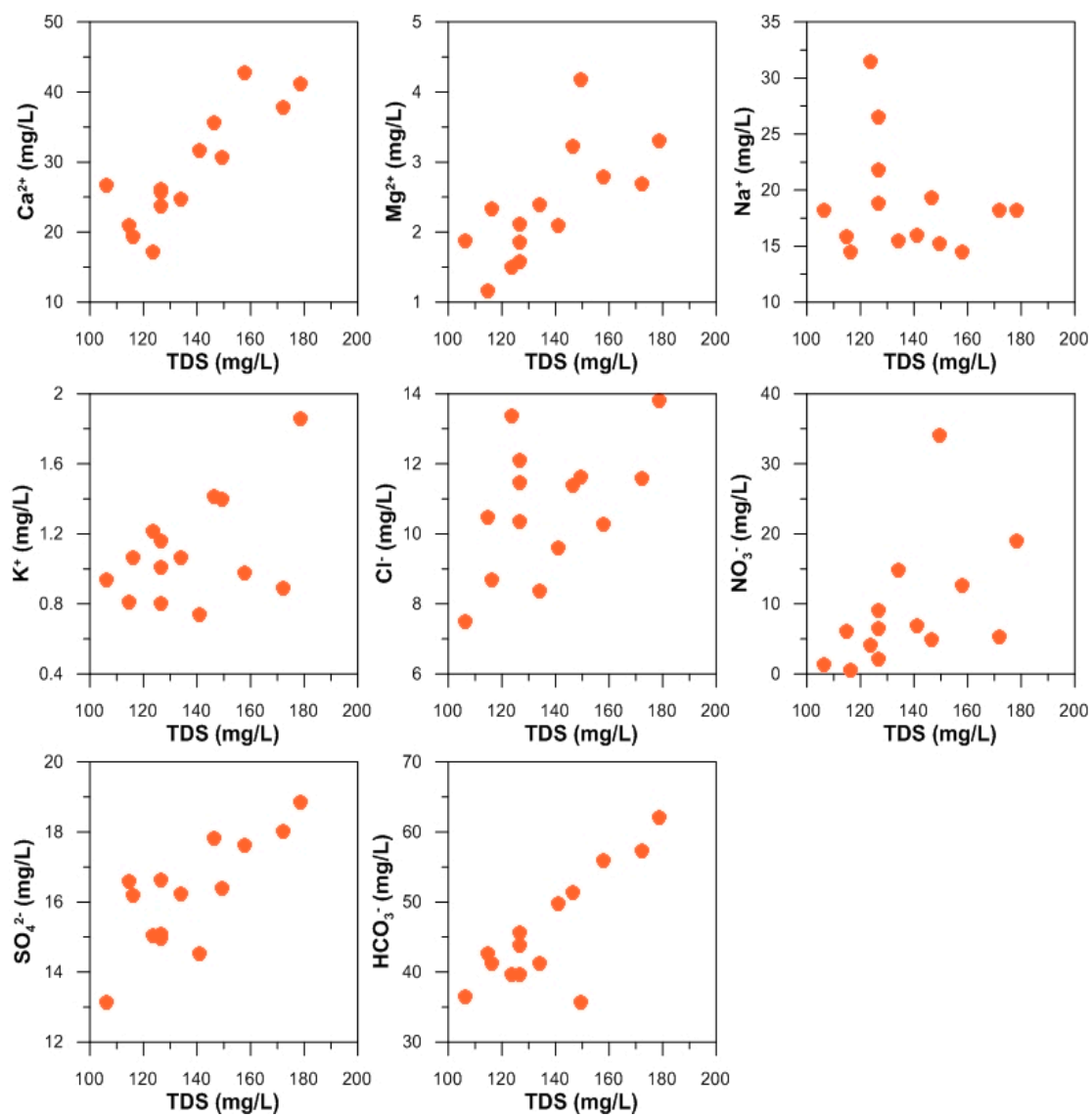

Figure 4. Variations in major ions according to TDS.

\subsection{Culturable Bacteria Based on GWHP Operation}

Two species of psychrophilic bacteria (Paenibacillus elgii and Paenibacillus lautus) and one species of mesophilic bacteria (Lysobacter mobilis) was obtained for psychrophilic $\left(10^{\circ} \mathrm{C}\right)$ and mesophilic $\left(28{ }^{\circ} \mathrm{C}\right)$ bacteria, whereas we obtained high colony counts for thermophilic $\left(45^{\circ} \mathrm{C}\right)$ bacteria (Table 1$)$. The detected concentration of culturable bacteria based on operation of the SY-3 GWHP from August 2014 to November 2016 was relatively high in samples collected in August 2014 and August 2016 $\left(1.6 \times 10^{9}\right.$ and $1.0 \times 10^{9} \mathrm{CFU} / \mathrm{L}$, respectively) (Table 1$)$. We speculated that this was due to the relatively high atmospheric and water temperatures during the summer season in the study area (Figure 5). The detected concentration of culturable bacteria in the samples collected during months other than August ranged from $1.0 \times 10^{7} \mathrm{CFU} / \mathrm{L}$ to $7.4 \times 10^{8} \mathrm{CFU} / \mathrm{L}$, which was lower than samples collected during the summer season.

Table 1. Colony counts of culturable thermophilic bacteria.

\begin{tabular}{|c|c|c|c|}
\hline \# & Sample & Date & CFU/L \\
\hline 1 & & 13 August 2014 & $1.6 \times 10^{9}$ \\
\hline 2 & & 28 October 2014 & $7.0 \times 10^{7}$ \\
\hline 3 & & 2 December 2014 & $9.0 \times 10^{7}$ \\
\hline 4 & SY-3 & 9 November 2015 & $2.9 \times 10^{8}$ \\
\hline 5 & & 27 May 2016 & $7.4 \times 10^{8}$ \\
\hline 6 & & 25 August 2016 & $1.0 \times 10^{8}$ \\
\hline 7 & & 24 November 2016 & $1.0 \times 10^{7}$ \\
\hline
\end{tabular}




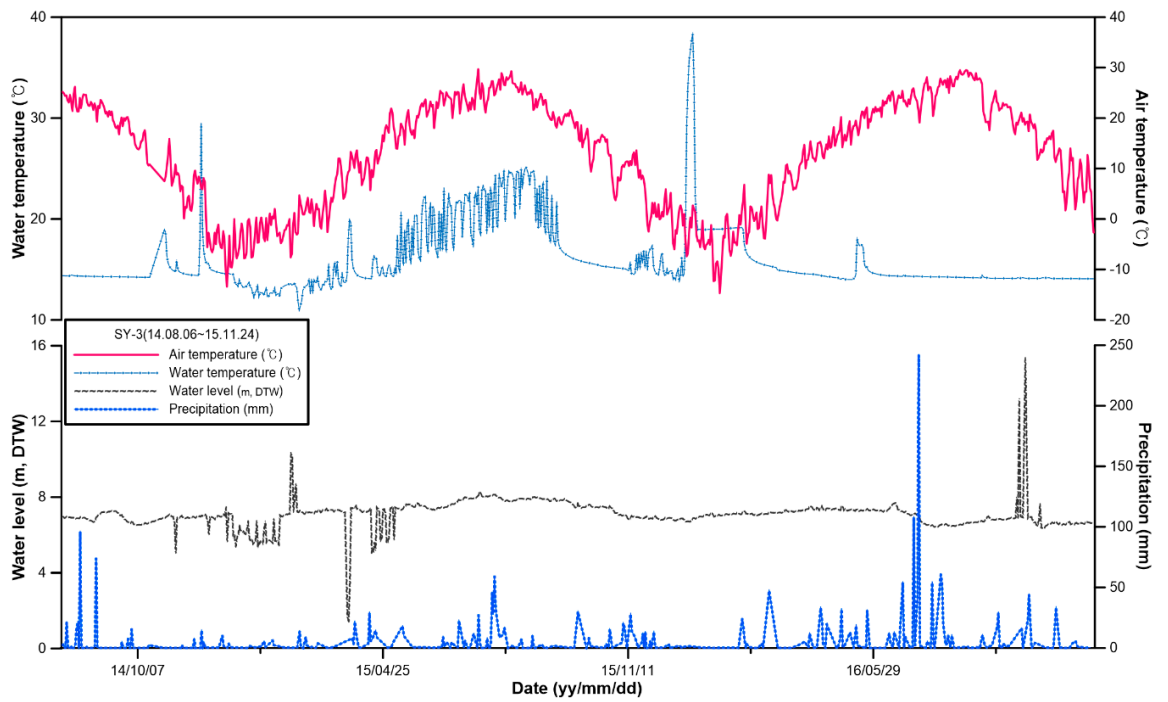

Figure 5. Air temperature, precipitation, water level, and water temperature measured at the study site from 13 August 2014, to 24 November 2016.

\subsection{Identified Bacteria}

The results of bacterial identification are presented in Table 2. The Anoxybacillus genus reportedly includes 23 species and subspecies, with Anoxybacillus amylolyticus representing the type species. The major sites of isolation included hot springs, fertilizers, and geothermal power plants [36]. The Anoxybacillus genus comprises rod-shaped, Gram-positive bacteria (size: 0.4-0.9 $\times 2.5-5.0 \mu \mathrm{m}$ ) frequently arranged as a pair or chain, with a single pore per cell. The oxygen demand and catalase reaction varied, with some members being anaerobic and others facultatively anaerobic. The bacteria were either alkalophilic or alkalophobic, and the DNA G+C content ranged from $42 \%$ to $57 \%$ [37].

Table 2. Identification and isolation of major and specific thermophilic bacteria.

\begin{tabular}{|c|c|c|c|c|c|}
\hline & Sample & Isolate & Strain & Hit & Similarity $(\%)$ \\
\hline \multirow{14}{*}{ SY-3 } & \multirow[t]{2}{*}{13 August 2014} & Major & $1 \mathrm{M}$ & $\begin{array}{c}\text { Vulcaniibacterium } \\
\text { thermophilum }\end{array}$ & 99.9 \\
\hline & & Specific & 11 & Anoxybacillus tepidamans & 98.8 \\
\hline & \multirow{2}{*}{28 October 2014} & Major & $2 \mathrm{M}$ & Anoxybacillus tepidamans & 98.8 \\
\hline & & Specific & 21 & Effusibacillus pohliae & 99.2 \\
\hline & \multirow{2}{*}{2 December 2014} & Major & $3 \mathrm{M}$ & Anoxybacillus tepidamans & 98.8 \\
\hline & & Specific & 31 & Anoxybacillus tepidamans & 98.9 \\
\hline & \multirow{2}{*}{9 November 2015} & Major & $4 \mathrm{M}$ & Deinococcus geothermalis & 98.1 \\
\hline & & Specific & 41 & Anoxybacillus tepidamans & 98.6 \\
\hline & \multirow{2}{*}{27 May 2016} & Major & $5 \mathrm{M}$ & Effusibacillus pohliae & 99.3 \\
\hline & & Specific & 51 & Not determined & - \\
\hline & \multirow{2}{*}{25 August 2016} & Major & $6 \mathrm{M}$ & Anoxybacillus tepidamans & 98.7 \\
\hline & & Specific & 61 & Anoxybacillus tepidamans & 98.8 \\
\hline & \multirow{2}{*}{24 November 2016} & Major & $7 \mathrm{M}$ & Effusibacillus pohliae & 99.2 \\
\hline & & Specific & 71 & Bacillus oceanisediminis & 99.4 \\
\hline
\end{tabular}

Filippidou et al. [38] isolated a strain of Anoxybacillus from deposits clogging ground surface filters at geothermal power plants in a field of enhanced geothermal systems in the Groß Schönebeck region of northern Germany, which formed endospores that are thermophilic, Gram-positive, facultatively anaerobic, and positive for catalase and oxidase reactions. Additionally, Dai et al. [39] isolated a thermophilic and ethanol-resistant strain of Anoxybacillus from deposit samples collected from groundwater wells at a hot spring in Yunnan Province in China. Schäffer et al. [40] isolated a bacterial strain from geothermally heated soil samples collected from Yellowstone National Park in the United 
States, identified by Coorevits et al. [41] as belonging to the Anoxybacillus genus (subsequently named Anoxybacillus tepidamans.

Anoxybacillus spp. are found abundantly in areas close to geothermal power plants and hot springs, and from which they are easily isolated. According to previous studies, bacteria belonging to this genus are resistant to hostile environmental conditions, such as high temperature and $\mathrm{pH}$, and capable of continuously increasing colony number to ultimately promote bio-clogging. In this study, seven of 14 species of thermophilic bacteria isolated and identified from SY-3 were identified as $A$. tepidamans, with a sequence homology of $98.6 \%$ to $98.9 \%$.

The strain of bacteria isolated from the SY-3 GWHP (24 November 2016) was identified as $99.4 \%$ Bacillus oceanisediminis, which was first reported by Zhang et al. [42]. B. oceanisediminis is a rod-shaped (size: $0.6-0.8 \times 2.0-3.0 \mu \mathrm{m}$ ), anaerobic, Gram-positive bacteria that we isolated at $45^{\circ} \mathrm{C}$, despite the optimal growth conditions requiring $37^{\circ} \mathrm{C}$. Because the strain grows within a temperature range of $4{ }^{\circ} \mathrm{C}$ to $45^{\circ} \mathrm{C}$, it is difficult to classify it as a thermophilic bacterium.

To date, 59 species of Deinococcus have been reported, with Deinococcus radiodurans representing the type species. In this study, the dominant culturable bacteria isolated from the SY-3 GWHP (November 9,2015 ) was identified as $98.1 \%$ Deinococcus geothermalis, which has an optimal growth temperature of $45^{\circ} \mathrm{C}$ to $50{ }^{\circ} \mathrm{C}$ and is classified as a thermophilic bacterium. D. geothermalis is particularly important to the formation of biofilms [43]. According to Kolari et al. [43], biofilms formed by D. geothermalis negatively influence the product quality from paper manufacturing machines. Additionally, this species should be managed as an important microorganism capable of biofilm formation. It can reduce thermal efficiency and degrade the system integrity of machines and wells associated with GWHP systems installed in the study area.

Effusibacillus pohliae was also isolated from the SY-3 GWHP. The Effusibacillus genus was first reported by Watanabe et al. [44], and little is known about the three known species. Effusibacillus spp. are spore-forming, rod-shaped, anaerobic or facultatively anaerobic chemotrophs. The Lysobacter genus includes 13 species and are mainly isolated from soil environments. In this study, the strain of mesophilic bacteria isolated from the SY-3 GWHP samples (13 August 2014) was identified as $97.2 \%$ Lysobacter mobilis. The Lysobacter genus comprises Gram-negative bacteria characterized by gliding motility and generally categorized as beneficial microorganisms. These bacteria produce enzymes that exhibit diverse functions, as well as reported sources of a novel antibiotic.

Paenibacillus spp. includes 200 species and subspecies of facultatively anaerobic bacteria that form endospores and originate from multiple habitats, such as soil, water, and plants. In this study, among the SY-3 regions, samples collected on 27 May 2016, and 25 August 2016, resulted in isolation of two strains identified as Paenibacillus elgii and Paenibacillus lautus. The first reported isolation of P. elgii was from perilla seeds and resulted in identification of a rod-shaped bacterium with motility. P. lautus was reclassified from Bacillus lautus by Heyndrickx et al. [45]. Neither of the two strains has shown strain-specific functionality. Paenibacillus is a mesophilic bacterium that can grow in temperatures up to $45^{\circ} \mathrm{C}$, thereby classifying is as a psychrophilic bacterium.

The Vulcaniibacterium genus, first reported by Yu et al. [46], includes Vulcaniibacterium tengchongense and Vulcaniibacterium thermophilum is Gram-negative bacteria that can grow in temperatures ranging from $25^{\circ} \mathrm{C}$ to $55^{\circ} \mathrm{C}$, classifying them as mesophilic bacteria.

Here, we describe collection and analysis of groundwater samples from tubular wells installed at the GWHP between 2014 and 2016 in order to investigate correlations between water temperature and microbial activity. Physicochemical data and microorganism activity (psychrophilic, mesophilic, and thermophilic bacteria) revealed microbial distribution in groundwater at the study area, with an excessively high level of thermophilic bacteria and with microbial count increasing according to increases in water temperature during the summer season. Investigation of the effects of temperature on the growth of the isolated and identified culturable bacteria identified eight species of bacteria (5 thermophilic bacteria, 1 mesophilic bacterium, and 2 psychrophilic bacteria). A. tepidamans was the most dominant thermophilic bacteria in the study area, with this genus having previously been 
reported as capable of creating bio-clogging deposits in wells and above-ground filters at geothermal power plants. Our experimental results showed that changes in groundwater temperature according to on-site management of the GWHP had a greater influence on the activity of thermophilic bacteria than on psychrophilic bacteria among autochthonous bacteria. Analysis of the thermal efficiency of the GWHP will benefit from studies on thermophilic bacterial cultures, and contribute to the understanding of bio-clogging phenomena that is possibly mediated by A. tepidamans. Furthermore, our results imply that quantitative and qualitative studies of autochthonous bacteria inhabiting areas near GWHPs should be conducted using next-generation sequencing to determine microbial community structures.

\section{Conclusions}

To investigate the correlation between water temperature and microbial activity in the groundwater collected from tubular wells installed at the GWHP, sample collection was conducted seven times during the period between 2014 and 2016. Furthermore, using the samples collected from the study area, physicochemical data and the activity of microorganisms (psychrophilic, mesophilic, and thermophilic bacteria) were examined. The microbial distribution in the groundwater of the study area showed a high level of thermophilic bacteria, while the microbial count increased according to the increase in water temperature during the summer season. The results of the investigation of how temperature affected the growth of the isolated and identified culturable bacteria are as follows: The microbial culture reported 8 species of bacteria, where 5 species of thermophilic bacteria (Anoxybacillus tepidamans, Bacillus oceanisediminis, Deinococcus geothermalis, Effusibacillus pohliae, and Vulcaniibacterium thermophilum) were isolated, and where one species of mesophilic (Lysobacter mobilis) and two species of psychrophilic (Paenibacillus elgii and Paenibacillus lautus) bacteria were identified. Anoxybacillus tepidamans was found to be the most dominant thermophilic bacteria in the study area. The Anoxybacillus genus, in particular, is known to create deposits that clog the wells and the filters above ground at geothermal power plants. The experimental results showed that the changes in groundwater temperature depending on the on-site management of the GWHP had greater influence on the activity of thermophilic bacteria than on the psychrophilic bacteria among autochthonous bacteria, and for the thermal efficiency of the GWHP, the study on the culture of thermophilic bacteria is anticipated to contribute to the understanding of the bioclogging phenomena mediated by Anoxybacillus tepidamans, which may be exerting a negative influence. Furthermore, it seems necessary that in addition to the experiments on the culturable bacteria in this study, more quantitative and qualitative studies on the autochthonous bacteria inhabiting the area around the GWHP should be conducted based on next-generation sequencing for microbial community structures.

Supplementary Materials: The following are available online at http://www.mdpi.com/2073-4441/11/10/2084/s1, Figure S1: Location map of the study area showing the monitoring well for groundwater samples.

Author Contributions: Conceptualization, H.K.; methodology, H.K.; validation, H.K. and J.-Y.L.; formal analysis, H.K.; investigation, H.K.; resources, H.K. and J.-Y.L.; data curation, H.K.; writing-original draft preparation, H.K.; writing-review and editing, H.K. and J.-Y.L.; visualization, H.K.; supervision, J.-Y.L.; funding acquisition, J.-Y.L.

Funding: This work supported by Basic Science Research Program through the National Research Foundation of Korea (NRF) grant funded by the Ministry of Education (No. 2019R1A6A1A03033167).

Conflicts of Interest: The authors declare no conflict of interest.

\section{References}

1. Boyle, G. Renewable Energy; Oxford University Press: Oxford, UK, 2004.

2. Quaschning, V.V. Renewable Energy and Climate Change; Wiley: Leicester, UK, 2010.

3. Lee, J.Y. Current status of ground source heat pumps in Korea. Renew. Sustain. Energy Rev. 2009, 13, 1560-1568. [CrossRef]

4. Hahn, J.; Han, H.; Hahn, C.; Kim, H.S.; Jeon, J.S. Design guidelines of geothermal heat pump system using standing column well. Econ. Environ. Geol. 2006, 39, 607-613. 
5. Snijders, A.L.; Drijver, B.C. Open-loop heat pump and thermal energy storage systems. In Advances in Ground-Source Heat Pump Systems; Woodhead Publishing: Dexford, UK, 2016; pp. 247-268.

6. Kim, H.; Mok, J.K.; Park, Y.; Kaown, D.; Lee, K.K. Composition of Groundwater Bacterial Communities before and after Air Surging in a Groundwater Heat Pump System According to a Pyrosequencing Assay. Water 2017, 9, 891. [CrossRef]

7. Park, Y.; Mok, J.K.; Jang, B.J.; Lee, J.Y.; Park, Y.C. Influence of closed loop ground source heat pumps on groundwater: A case study. J. Geol. Soc. Korea 2015, 51, 243-251. (In Korean) [CrossRef]

8. Casasso, A.; Sethi, R. Assessment and Minimization of Potential Environmental Impacts of Ground Source Heat Pump (GSHP) Systems. Water 2019, 11, 1573. [CrossRef]

9. García-Gil, A.; Gasco-Cavero, S.; Garrido, E.; Mejías, M.; Epting, J.; Navarro-Elipe, M.; Alejandre, C.; Sevilla-Alcaine, E. Decreased waterborne pathogenic bacteria in an urban aquifer related to intense shallow geothermal exploitation. Sci. Total Environ. 2018, 633, 765-775. [CrossRef]

10. García-Gil, A.; Epting, J.; Garrido, E.; Vázquez-Suñé, E.; Lázaro, J.M.; Sánchez Navarro, J.Á.; Huggenberger, P.; Calvo, M.Á.M. A city scale study on the effects of intensive groundwater heat pump systems on heavy metal contents in groundwater. Sci. Total Environ. 2016, 572, 1047-1058. [CrossRef]

11. Bucci, A.; Prevot, A.B.; Buoso, S.; De Luca, D.A.; Lasagna, M.; Malandrino, M.; Maurino, V. Impacts of borehole heat exchangers (BHEs) on groundwater quality: The role of heat-carrier fluid and borehole grouting. Environ. Earth Sci. 2018, 77, 175. [CrossRef]

12. Klotzbücher, T.; Kappler, A.; Straub, K.L.; Haderlein, S.B. Biodegradability and groundwater pollutant potential of organic anti-freeze liquids used in borehole heat exchangers. Geothermics 2007, 36, 348-361. [CrossRef]

13. Bonte, M.; Röling, W.F.M.; Zaura, E.; Van Der Wielen, P.W.J.J.; Stuyfzand, P.J.; Van Breukelen, B.M. Impacts of shallow geothermal energy production on redox processes and microbial communities. Environ. Sci. Technol. 2013, 47, 14476-14484. [CrossRef]

14. Griebler, C.; Brielmann, H.; Haberer, C.M.; Kaschuba, S.; Kellermann, C.; Stumpp, C.; Hegler, F.; Kuntz, D.; Walker-Hertkorn, S.; Lueders, T. Potential impacts of geothermal energy use and storage of heat on groundwater quality, biodiversity, and ecosystem processes. Environ. Earth Sci. 2016, 75, 1391. [CrossRef]

15. Rafferty, K.D. Water Chemistry Issues in Geothermal Heat Pump Systems. Ashrae Trans. 2004, 110, 550.

16. Sanner, B.; Karytsas, C.; Mendrinos, D.; Rybach, L. Current status of ground source heat pumps and underground thermal energy storage in Europe. Geothermics 2003, 32, 579-588. [CrossRef]

17. Lund, J.; Sanner, B.; Rybach, L.; Curtis, R.; Hellström, G. Geothermal (ground-source) heat pumps: A world overview. Geo-Heat Cent. Bull. 2004, 25, 1-10.

18. Gao, Q.; Li, M.; Yu, M.; Spitler, J.D.; Yan, Y.Y. Review of development from GSHP to UTES in China and other countries. Renew. Sustain. Energy Rev. 2009, 13, 1383-1394. [CrossRef]

19. Abesser, C. Open-Loop Ground Source Heat Pumps and the Groundwater Systems: A Literature Review of Current Application, Regulations and Problems; Energy Geoscience Programme Open Report OR/10/045; British Geological Survey: Nottingham, UK, 2010.

20. Bonte, M. Impacts of Shallow Geothermal Energy on Groundwater Quality-A Hydrochemical and Geomicrobial Study on the Effects of Ground Source Heat Pumps and Aquifer Thermal Energy Storage. Ph.D. Thesis, VU University Amsterdam, Amsterdam, The Netherlands, 2013.

21. Antics, M.; Bertani, R.; Sanner, B. Summary of EGC 2016 Country Update Reports on Geothermal Energy in Europe. In Proceedings of the European Geothermal Congress 2016, Strasbourg, France, 19-24 September 2016; pp. 1-16.

22. Park, Y.; Kim, N.; Lee, J.Y. Geochemical properties of groundwater affected by open loop geothermal heat pump systems in Korea. Geosci. J. 2015, 19, 515-526. [CrossRef]

23. York, K.P.; Jahangir, Z.M.G.S.; Solomon, T.; Stafford, L. Effects of a large scale geothermal heat pump installation on aquifer microbiota. In Proceedings of the 2nd Stockton International Geothermal Conference, Stockton, NJ, USA, 16-17 March 1998; p. 8.

24. Jo, Y.J.; Lee, J.Y.; Lim, S.Y.; Hong, G.P. A review on potential effects of installation and operation of ground source heat pumps on soil and groundwater environment. J. Soil Groundw. Environ. 2009, 14, $22-31$.

25. Jo, Y.J.; Lee, J.Y.; Kim, C.G.; Han, J.S. Effects of grouts and temperature change on microorganisms in geothermal heat pump. J. Soil Groundw. Environ. 2009, 14, 10-14. 
26. Saner, D.; Juraske, R.; Kübert, M.; Blum, P.; Hellweg, S.; Bayer, P. Is it only $\mathrm{CO}_{2}$ that matters? A life cycle perspective on shallow geothermal systems. Renew. Sustain. Energy Rev. 2010, 14, 1798-1813. [CrossRef]

27. Bayer, P.; Saner, D.; Bolay, S.; Rybach, L.; Blum, P. Greenhouse gas emission savings of ground source heat pump systems in Europe: A review. Renew. Sustain. Energy Rev. 2012, 16, 1256-1267. [CrossRef]

28. Rivoire, M.; Casasso, A.; Piga, B.; Sethi, R. Assessment of Energetic, Economic and Environmental Performance of Ground-Coupled Heat Pumps. Energies 2018, 11, 1941. [CrossRef]

29. Houben, G.; Treskatis, C. Water Well Rehabilitation and Reconstruction; McGraw-Hill: New York, NY, USA, 2007.

30. Smith, S.A.; Comeskey, A.E. Sustainable Wells: Maintenance, Problem Prevention, and Rehabilitation; CRC Press: Boca Raton, FL, USA, 2009.

31. van Beek, C.K. Cause and Prevention of Clogging of Wells Abstracting Groundwater from Unconsolidated Aquifers; IWA Publishing: London, UK, 2011.

32. Burté, L.; Cravotta, C.; Bethencourt, L.; Farasin, J.; Pédrot, M.; Dufresne, A.; Gérard, M.-F.; Baranger, C.; Le Borgne, T.; Aquilina, L. Kinetic study on clogging of a geothermal pumping well triggered by mixing-induced biogeochemical reactions. Environ. Sci. Technol. 2019, 53, 10. [CrossRef] [PubMed]

33. Mirza, M.M.Q. The Ganges Water Diversion: Environmental Effects and Implications; Springer: Dordrecht, The Netherlands, 2004; pp. 93-95.

34. Chadha, D.K. A proposed new diagram for geochemical classification of natural waters and interpretation of chemical data. Hydrogeol. J. 1999, 7, 431-439. [CrossRef]

35. Schneider, E.A.G.; García-Gil, A.; Vázquez-Suñè, E.; Sánchez-Navarro, J.Á. Geochemical impacts of groundwater heat pump systems in an urban alluvial aquifer with evaporitic bedrock. Sci. Total Environ. 2016, 544, 354-368. [CrossRef] [PubMed]

36. Belduz, A.O.; Dulger, S.; Demirbag, Z. Anoxybacillus gonensis sp. nov., a moderately thermophilic, xylose-utilizing, endospore-forming bacterium. Int. J. Syst. Evol. Microbiol. 2003, 53, 1315-1320. [CrossRef]

37. Pikuta, E.; Cleland, D.; Tang, J. Aerobic growth of Anoxybacillus pushchinoensis $\mathrm{K}^{\mathrm{T}}{ }^{\mathrm{T}}$ : Emended descriptions of A. pushchinoensis and the genus Anoxybacillus. Int. J. Syst. Evol. Microbiol. 2003, 53, 1561-1562. [CrossRef]

38. Filippidou, S.; Jaussi, M.; Junier, T.; Wunderlin, T.; Jeanneret, N.; Palmieri, F.; Palmieri, I.; Roussel-Delif, L.; Vieth-Hillebrand, A.; Vetter, A.; et al. Anoxybacillus geothermalis sp. nov., a facultatively anaerobic, endospore-forming bacterium isolated from mineral deposits in a geothermal station. Int. J. Syst. Evol. Microbiol. 2016, 66, 2944-2951. [CrossRef]

39. Dai, J.; Liu, Y.; Lei, Y.; Gao, Y.; Han, F.; Xiao, Y.; Peng, H. A new subspecies of Anoxybacillus flavithermus ssp. yunnanensis ssp. nov. with very high ethanol tolerance. FEMS Microbiol. Lett. 2011, 320, 72-78.

40. Schäffer, C.; Franck, W.L.; Scheberl, A.; Kosma, P.; McDermott, T.R.; Messner, P. Classification of isolates from locations in Austria and Yellowstone National Park as Geobacillus tepidamans sp. nov. Int. J. Syst. Evol. Microbiol. 2004, 54, 2361-2368. [CrossRef]

41. Coorevits, A.; Dinsdale, A.E.; Halket, G.; Lebbe, L.; De Vos, P.; Van Landschoot, A.; Logan, N.A. Taxonomic revision of the genus Geobacillus: Emendation of Geobacillus, G. stearothermophilus, G. jurassicus, G. toebii, G. thermodenitrificans and G. thermoglucosidans (nom. corrig., formerly 'thermoglucosidasius'); transfer of Bacillus thermantarcticus to the genus as G. thermantarcticus comb. nov.; proposal of Caldibacillus debilis gen. nov., comb. nov.; transfer of G. tepidamans to Anoxybacillus as A. tepidamans comb. nov.; and proposal of Anoxybacillus caldiproteolyticus sp. nov. Int. J. Syst. Evol. Microbiol. 2012, 62, 1470-1485.

42. Zhang, J.; Wang, J.; Fang, C.; Song, F.; Xin, Y.; Qu, L.; Ding, K. Bacillus oceanisediminis sp. nov., isolated from marine sediment. Int. J. Syst. Evol. Microbiol. 2010, 60, 2924-2929. [CrossRef] [PubMed]

43. Kolari, M.; Nuutinen, J.; Salkinoja-Salonen, M.S. Mechanisms of biofilm formation in paper machine by Bacillus species: The role of Deinococcus geothermalis. J. Ind. Microbiol. Biotechnol. 2001, 27, 343-351. [CrossRef] [PubMed]

44. Watanabe, M.; Kojima, H.; Fukui, M. Proposal of Effusibacillus lacus gen. nov., sp. nov., and reclassification of Alicyclobacillus pohliae as Effusibacillus pohliae comb. nov. and Alicyclobacillus consociatus as Effusibacillus consociatus comb. nov. Int. J. Syst. Evol. Microbiol. 2014, 64, 2770-2774. [CrossRef] [PubMed] 
45. Heyndrickx, M.; Vandemeulebroecke, K.; Scheldeman, P.; Kersters, K.; De Vos, P.; Logan, N.A.; Aziz, A.M.; Ali, N.; Berkeley, R.C.W. A polyphasic reassessment of the genus Paenibacillus, reclassification of Bacillus lautus (Nakamura 1984) as Paenibacillus lautus comb. nov. and of Bacillus peoriae (Montefusco et al. 1993) as Paenibacillus peoriae comb. nov., and emended descriptions of P. lautus and of P. peoriae. Int. J. Syst. Evol. Microbiol. 1996, 46, 988-1003.

46. Yu, T.T.; Zhou, E.M.; Yin, Y.R.; Yao, J.C.; Ming, H.; Dong, L.; Nie, G.X.; Li, W.J. Vulcaniibacterium tengchongense gen. nov., sp. nov. isolated from a geothermally heated soil sample, and reclassification of Lysobacter thermophilus Wei et al. 2012 as Vulcaniibacterium thermophilum comb. nov. Antonie van Leeuwenhoek 2013, 104, 369-376. [CrossRef]

(C) 2019 by the authors. Licensee MDPI, Basel, Switzerland. This article is an open access article distributed under the terms and conditions of the Creative Commons Attribution (CC BY) license (http://creativecommons.org/licenses/by/4.0/). 